\title{
The Right to Development and its Corresponding Obligations on Developing Countries
}

\author{
Ahmad Masum
}

\begin{abstract}
The right to development is a fundamental right, the precondition of liberty, progress, justice and creativity. This right has raised many expectations and controversies over the years. Developing countries claim that the international economic and political order constitutes an obstacle to the enjoyment of the right to development for their citizens. They therefore see a need for action in the international dimension of the right to development. In their view, they are able to provide the necessary basis for the enjoyment of the right to development only if the international order becomes more conducive to the economic development of developing countries. This paper aims to examine the concept of the right to development as a 'human right' focusing mainly on the position of developing countries as to whether they have an obligation to work towards the realization and implementation of this right. The paper concludes that the right to development is now recognized as a 'human right' like other internationally accepted human rights. Thus, being a right, it entails obligations of some agents in the society, who have the power to deliver the right or adopt policies that have a high likelihood of delivering the right.
\end{abstract}

Keywords: Developing countries, enjoyment, human rights, liberty, right to development.

\section{Introduction}

Less than two decades ago, human rights considerations were rarely addressed in the context of development policy. The reasons were diverse. Some economists considered human rights to be political in contrast to the more technical challenges promoting economic development, some felt that many or even most human rights concerns were not to be quantified effectively and thus could not be factored into development equation, others were sympathetic to the idea that respect for civil and political rights was an issue that first required a significant degree of development to be attained, and some rejected the notion of economic and social rights as running counter to the functioning of free markets (Steiner, Alston, \& Goodman, 2008). It was not until the early 1990s that a more sophisticated debate began to take place. It was fuelled partly by the failure of old development models, and partly by the realization that notions of good governance, participation, accountability and transparency inevitably had human rights dimensions and could not be promoted adequately without addressing those dimensions (Steiner, Alston, \& Goodman, 2008). One of the most influential contributors to the debate has been Amartya Sen (1999) who argues that freedom should be seen as both the ends and the means to development. 
The discourse on the right to development (RTD) has evolved significantly since it was proclaimed in the Declaration on the Right to Development in 1986. This right was adopted in 1986 by the United Nations General Assembly (GA) in its resolution 41/128. This right is also recognized in the African Charter on Human and Peoples' Rights and the Arab Charter on Human Rights and re-affirmed in several instruments including the 1992 Rio Declaration on Environment and Development, the 1993 Vienna Declaration and Programme of Action, the Millennium Declaration, the 2002 Monterry Consensus, the 2005 World Submit Outcome Document and the 2007 Declaration on the Rights of Indigenous Peoples (United Nations Human Rights- Office of the Commissioner for Human RightsInformation Materials, 1996-2013).It is important to note that the international dimension of the RTD is nothing other than the right to equitable share in the economic and social wellbeing of the world. Hence, the duty to implement all human rights applies to all developed and developing countries, whether individuals suffer from the lack of these rights. The RTD is a special right, in the sense that it is a composite of all, or at least the basic right of citizens in both developed and developing countries.

This paper aims to examine the concept of the RTD focusing mainly on the position of the developing countries in the context of their obligations towards the realization and implementation of this right. The paper is divided into four parts. The first part focuses on the meaning of the RTD looking at its legal validity. The second part deals with the 'subjects of the right to development' and whether states i.e. developing countries owe a duty or an obligation to these subjects in the realization and implementation of this right. The third part turns attention to the developing countries in their quest for the realization and implementation of the RTD and the challenges that they face. The fourth part shall focus on the conclusion, which will embrace some recommendations for the purpose and implementation of the RTD and mechanisms and policies to be adopted by developing countries to enable the realization of this right in a progressive manner.In this paper, the author argues that the very essence of the RTD is simple, comprehensive and clear: it is the right to a national and international environment that enables or at least does not hinder the enjoyment by individuals and peoples of their basic human rights and fundamental freedoms, an environment that is free from structural and unfair obstacles to development.

\section{The Meaning of the Right to Development}

The RTD is an inalienable human right by virtue of which every human person and all peoples are entitled to participate in, contribute to, and enjoy economic, social, cultural and political development, in which all human rights and fundamental freedoms can be fully realized (Art 1.1, Declaration on the Right to Development 1986). The RTD has several aspects, the most important and comprehensive of which is the right of each people freely to choose its economic and social system without outside interference or constraint of any kind, and to determine, with equal freedom, its own model of development (Bedjaoui, 1991). It could be argued that the 'right to development' flows from this to self-determination and 
has the same nature. There is little sense in recognizing self-determination as a superior and inviolable principle if one does not recognize at the same time a 'right to development' for the peoples that have achieved self-determination (Bedjaoui, 1991). Hence, this RTD can only be an 'inherent' and 'built-in' right forming an inseparable part of the right to self determination. This makes the RTD much more a right of the State or the people, than a right of the individual, and it seems to me that is the better way (Bedjaoui, 1991). Jack Donnelly (1985) disagreed with the notion that the RTD flows from the right to selfdetermination. He argued that a substantially broader RTD cannot be extracted from this right to self-determination. The right to self determination recognized in the Covenants does not imply a right to live in a developing society; it is explicitly only a right to pursue development. Neither does it imply an individual right to development; self-determination, again explicitly, is a right of peoples only. In no sense does it imply a right to be developed. Thus, the claim that the RTD is simply the realization of the right to self-determination is not based on the Covenants' understanding of self-determination.

Furthermore, to Jack Donnelly (1985), it might be argued that because development is necessary for self-determination, development itself is a human right. Such an argument, however, is fallacious. He argued that even assuming that development is necessary for, rather than a consequence of, full enjoyment of the right to self-determination, it simply does not follow that peoples have a RTD. Allowing such an argument to prevail would result in a proliferation of bizarre or misguided rights. Hence, it would suffice to note that judging from the views of Bedjaoui (1991) and Jack Donnelly (1985) there seems to be some degree of confusion regarding the meaning of the term RTD especially in the context of who are the subjects of this right.

Regardless of the debates surrounding how the RTD should be approached, it appears that the first Article of the Declaration contains three principles which the other articles and paragraph of the Declaration elaborate. Arjun Sengupta (2002), former independent expert on the 'right to development', describes them as follows: "(a) there is an inalienable human right that is called the right to development; (b) there is a particular process of economic, social, cultural and political development, in which all human rights and fundamental freedoms can be fully realized; and (c) the right to development is a human right by virtue of which every human person and all peoples are entitled to participate in, contribute to and enjoy that particular process of development" (Kirchmeier, 2006, p. 9).

This all-comprising but not very concise definition has led to anxieties in industrially developed countries that the 'right to development' could be seen as a "right to everything". The duty-bearers identified by the Declaration on the Right to Development are at the same time the nation state and the international community. So the debate has been mostly about reaching a narrower and more exact definition of this right and duties it invokes.

Having defined the RTD above, it is inevitable in the context of this paper to touch on the issue of whether it is a legally enforceable right and thus carrying with it a corresponding 
obligation on developing countries to ensure that such right is accorded protection and respected as well. At this juncture, it is important to note that the RTD is not yet a legally binding instrument, but draws its legal foundation from binding human rights covenants. From a legal point of view, the RTD can be described as "soft law". This term denotes a group of human rights which have been generally accepted by the world community and reaffirmed in declarations and resolutions by the leaders of many states. The legal foundation for the RTD therefore has to be sought in other (legally binding) documents. Examining the content of the RTD, it could be argued that the Bill of Human Rights can be taken as a foundation. The Universal Declaration of Human Rights 1948 and the Covenants on Civil and Political Rights 1966 and on Economic, Social and Cultural Rights 1966 all have legally binding status for those states that are parties to the covenants. For those states who are not parties to the covenants, the author has, on the contrary, maintained that the RTD is, by its nature, so incontrovertible that it should be regarded as belonging to jus cogens i.e. a body of peremptory principles or norms in international law from which no derogation is permitted; those norms recognized by the international community as a whole as being fundamental to the maintenance of an international legal order.

\section{Subjects of the Right to Development}

Who are the right-holders of the RTD? In fact the issue of who are the subjects of the RTD has generated a lot of heated debates. The Declaration on the Right to Development 1986 simply states that "the right to development is an inalienable human right by virtue of which every human person and all peoples are entitled to participate in, contribute to, and enjoy economic, social, cultural and political development, in which all human rights and fundamental freedoms can be fully realized" (Art 1.1). It has been vociferously argued that not only does the Declaration mix up individual human rights and collective (people's) rights which are different and should be kept distinct but, since people as collective rights holders are not physical persons, they require an institutional person to exercise their rights (Donnelly, 1985). The most plausible 'person' to exercise such people's rights is, unfortunately, the state. This represents a radical reconceptualization of human rights and especially dangerous one (Donnelly, 1985). It is dangerous because all human rights are held primarily against the state.

It would suffice to note that the idea of collective human rights represents a major, and at best confusing, conceptual deviation. But, looking at the other side of the spectrum it could be argued that if the human being as an individual is seen as the right-holder, there has to be a duty-bearer as well. In general- as in the case of civil, political, economic, social, and cultural rights, this duty-bearer is the nation state of which the right-holders are part. On the other hand, if the RTD is to be seen as a right of peoples (as groups of individual rightholders), states, and their governments in their capacity as representatives of the people, could figure as right-holders. States are also duty-bearers at the international level. They are required to control the internal distribution of resources and ensure good domestic 
governance, while rich states would also have the obligation to help poor states as far as their means allow them to do so.

In the context of this paper, perhaps what is important is to consider the RTD as the aggregate of the social, economic and cultural rights not of each individual, but of all the individuals constituting a collectivity (Abi-Saab, 1980). In other words, it is the sum total of a double aggregation of the rights and of the individuals. This version has the merit of shedding light on the link between the rights of the individual and the right of the collectivity; a link which is crucial as far as the subjects of the 'right to development' are concerned (Abi-Saab, 1980). Hence as far as the beneficiaries or active subjects are concerned, the first answer that comes to mind is that they are those societies possessing certain characteristics which lead the international community to consider them wanting in terms of development and to classify them as "developing or less developed countries" (Abi-Saab, 1980).

Despite the heated debates on who are the subjects of the RTD as addressed above, it is also pertinent to address the issue of whether developing countries have an obligation to these subjects towards the promotion, protection and fulfillment of this right. Under the Declaration on the Right to Development, "States have the primary responsibility for the creation of national and international conditions favourable to the realization of the right to development" (Art 3). Hence, it is arguable that if the 'right to development' is a human right, then states are duty-bound to guarantee it to everyone within their territorial jurisdiction. Indeed. Art 2(3) of the Declaration to the Right to Development 1986 recognizes the states' duty expressly. According to the high-level task force on the implementation of the right to development, "the responsibility for the creation of this enabling environment encompasses three main levels: (a) States acting collectively in global and regional partnerships (second preambular paragraph and Art 3); (b) States acting individually as they adopt and implement policies that affect persons not strictly within their jurisdiction (Art 4); and (c) States acting individually as they formulate national development policies and programmes affecting persons within their jurisdiction (Art 2)" (United Nations Human Rights- Office of the Commissioner for Human Rights- Information Materials, 1996-2013).

Furthermore, Art 6(3) of the Declaration on the Right to Development calls on states to take steps to eliminate obstacles to development resulting from the failure to observe civil and political rights as well as economic, social and cultural rights. The nature and context of these rights are crystallized in the International Covenants and the various related human rights instruments adopted under the auspices of the United Nations as mentioned earlier in the introduction. Hence, the notion of obstacles to human rights and fundamental freedoms is a momentous innovation. States are charged with a duty to remove these obstacles. Clearly, this assumes that the state itself will observe rights and freedoms, as otherwise it would itself constitute an obstacle to be removed by the people. It would therefore suffice to note that when a particular state structure or operation becomes an obstacle arising from a violation of human rights and fundamental freedoms, the right to development must indicate, if we read the Declaration as a whole, two component rights: the human right to reform state structures 
and processes and the human right to transform them where necessary (Symonides, 1998). From the above, it would suffice to note that the obligation to realize and implement the RTD applies to all developed or developing countries. Thus, the obligations are in this case not imposed on one individual state, i.e. as regards its internal structures, but on the international community, which is obliged "to promote fair development policies and effective international cooperation". In the context of this paper, it is still arguable that although international cooperation inform of partnership is needed in order to realize and implement effectively the RTD as a human right, this does not mean that developing countries should not make changes to their internal structures in order to fulfill the RTD for their citizens. In other words, the current discussion on the RTD should not focus widely on the international structures and negating the internal structures, which would require developing countries to do their part in the realization and implementation of the RTD. Hence, developing countries do have an obligation to their citizens by providing an environment conducive for the enjoyment of the RTD rather than relying heavily on developed countries invoking the notion of 'international co-operation' in their quest for the realization and implementation of the RTD.

\section{Challenges Faced by Developing Countries in the Realization and Implementation of the Right to Development}

Different countries or groups of countries promote different views on the RTD. The perceptions of what the RTD could mean or what its realization and implementation would require could not be more diverse. For example, Germany as a developed country supports and agrees to the concept of the RTD. However, it emphasizes the fact that the RTD does not necessarily focus on international cooperation, stressing instead that the primary duty to create an enabling environment lies with the developing states themselves (Kirchmeier, 2006). The following are some of the most pressing challenges faced by developing countries in their quest for the realization and implementation of the RTD:

First, the Declaration on the Right to Development is viewed as ambiguous. The language of the Declaration is vague, imprecise and unclear in some respects. First, it is not clear whether the individual is the subject or the beneficiary of the RTD (Lindroos, 1999). 'The individual as a subject' and as a 'beneficiary' create sufficient jurisprudential confusion and vagueness, hence significantly reflect on the problems involved in the justiciability of the RTD. Moreover, the state is not specifically mentioned as a subject of the RTD (KenigWitkowska, 1988). The Declaration merely provides that the state has the right and duty to formulate development policies (Art 2(3)).

Still on the issue of the ambiguity of the Declaration, it is also vital to note that while the principle of co-operation is one of the main features of the RTD, the language of the Declaration does not couch it in precise terms. A close reading of the Declaration would show that the words used are neither mandatory nor consistent (Iqbal, 2007). For example, 
Art 3(2) says that 'the realization ofthe [RTD] requires full respect of the principles of international law concerning friendly relations and cooperation...' With respect to the formulation of international development policies for the realization of the RTD, Art 4(1) says, 'States have the duty to take steps, individually and collectively'. Art 4(2) says that effective international cooperation is essential for supporting developing countries to achieve development. The language of this Art is compromising because it avoids identifying the duty-holder (i.e. developed countries) if at all there is a duty. Moreover, it does not explicitly speak about the mandatory nature of development aid provided by developed countries to developing countries. Similarly, the words 'should co-operate' are used in article 6(1), for promotion of all human rights without any distinction. The word 'duty' isused in Arts 3(3) and 4(1). The former says that the states have the duty to cooperate with each other in ensuring development and eliminating obstacles to development. The latter says, 'The states have the duty to take steps, individually and collectively, to formulate international development policies with a view to facilitating the full realization of the [RTD]'. The advocates of the RTD usually refer to Arts 55 and 56 of the UN charter as having a general recognition in international law, but some commentators (Turk, 1988) are of the view that 'the formulation of this principle remains rather abstract and permits a relatively wide margin of discretion regarding its practical interpretation and application.'

Second, learned opinion is divided in its view of the legal validity of the RTD. Many writers consider that while it is undoubtedly an inalienable and imperative right, this is only in the moral, rather than in the legal, sphere (Bedjaoui, 1991). For the RTD to be considered a legal right, it must be possible to identify the active and passive subjects of the right and its content (Abi-Saab, 1980). But those elements depend on the legal basis of the right, which in turn depends on whether the right is an individual or collective one. This point is closely related to the first challenge raised above. For example, some writers have considered the RTD as a collective right (Abi-Saab, 1980). On the other hand, some writers have argued that the RTD is an individual right and not a collective right on the basis of Art 28 of the UDHR being an implicit source of the RTD. According to Jack Donnelly (1985), if Art 28 is taken to imply a human right to development, we are most likely to encounter the issue of what would that right look like? To him, it would be an individual right, and only an individual right; a right of persons, not peoples, and certainly not States. It would be a right to the enjoyment of traditional human rights, not a substantively new right. It would be as much as civil and political as an economic and social right. Because of this problem, different countries (developed and developing) promote different views on the RTD. Take for instance the US, it is willing to "talk about an individual's right to development," but not a "nation's right to development, for the simple reason that nations do not have human rights" (Kirchmeier, 2006; Marks, 2004). The US also rejects, consequently, the elaboration of a legally binding instrument on the RTD (Kirchmeier, 2006).

Third, the exercise and enjoyment of the RTD presupposes the existence of and compliance with rights contained in the Declaration on the Right to Development 1986 and the two covenants (i.e. the International Covenant on Civil and Political Rights and the International Covenant on Economic, Social and Cultural Rights): the right to self-determination, 
education, work, life, health, food, housing, liberty and security of the person, etc. The RTD calls for an environment conducive to the realization of these rights. The responsibility therefore lies first with the state. This means that a politically and socially just and reliable system has to be established, granting those fundamental rights to everyone. Unfortunately, most developing countries suffer from a politically and socially just and reliable system. Absence of good domestic governance is perceived as a serious problem towards the realizationof the RTD in most developing countries. Most developing countries are too weak (or unwilling) to fulfill their duties, or where the power to do so is beyond their reach. It cannot be denied that most developing countries are unable to control the internal distribution of their resources and ensure good domestic governance.

Fourth, the fear by the developed countries that the RTD might be perceived as a "right to development assistance" especially in extending their helping hands to the developing countries in their quest for the realization and implementation of this right. Developing countries want to mainstream the RTD in the current international economic rules and policies. Developed countries are reluctant to concede this demand, arguing that they have no legal obligation to provide assistance to developing countries for their economic development (Iqbal, 2007). This has made developed countries very reluctant to engage in any discussions on the topic. For example, while developing countries called on developed countries to alter boththeir international policies and the international economic order, developed countries stressed the need for developing countries to change their internal structures in order to fulfill the right to development for their citizens (Kirchmeier, 2006). Developing countries claim that the international economic and political order constitutes an obstacle to the enjoyment of the RTD for their citizens (Kirchmeier, 2006; Sen, 2010). They therefore see a need for an action in the international dimension of the RTD. In their view, they are able to provide the necessary basis for the enjoyment of the RTD only if the international order becomes more conducive to the economic development of developing countries in general. Perhaps it is important to point out that developing countries seem to be building their case on the very core of the Declaration on the Right to Development, which was adopted in 1986 by the United Nations General Assembly (GA) in its resolution 41/128. The Declaration states that "The realization of the right to development requires full respect for the principles of international law concerning friendly relations and cooperation among States in accordance with the Charter of the United Nations" (Art 3(2)). Unless and until there is an international cooperation from developed countries, developing countries will always face a daunting task in their realization of the RTD.

Fifth, the absence of a functional approach to the definition of the RTD is seen as another challenge faced by developing countries in the realization of this right.We must remember that nearly twenty six years have elapsed since the right to development was formally recognized by the UN General Assembly as inalienable human rights (General Assembly resolution 41/128, Declaration on the Right to Development, December 4, 1986). Despite constant efforts, scholars and delegates alike continue to voice some degree of confusion with regard to its definition. Ultimately, the basic premise of the right to development 
finds its origin in Art 28 of the UDHR stating that "Everyone is entitled to a social and international order in which the rights and freedoms set forth in this Declaration can be fully realized". As a matter of fact, the similarities are clear between this Art and the first Art of the Right to Development General Assembly Declaration of 1986 stating that: "The right to development is an inalienable human right by virtue of which every human person and all peoples are entitled to participate in, contribute to, and enjoy economic, social, cultural and political development, in which all human rights and fundamental freedoms can be fully realized", as well as Art 3 of the same Declaration emphasizing that "States have the primary responsibility for the creation of national and international conditions favourable to the realization of the right to development." It is a human right which is both individual and collective, which depends more than any other human rights on international cooperation and which raises issues of norms and policy coherence among different disciplines and processes (Salama, 2008).

Still on the above challenge, many scholars have pointed out that these definitions do not lead to clarity and can result in significant ambiguity of the concept. Take for instance the United States (US) position which clearly shows some ambiguity. While the US has accepted the RTD in key documents, administration officials reject any responsibilities that could arise from an application of the right to development and generally vote against resolutions that would advance the RTD (Kirchmeier, 2006). The main objection to such resolutions was that the US understands the term RTD "to mean that each individual should enjoy the right to develop his or her intellectual or other capabilities to the maximum extent possible through the exercise of the full range of civil and political rights" (Kirchmeier, 2006, p. 14). On the other hand, the members of the African Union (AU) committed themselves in the Banjul Charter (Art 22), which dates to a time prior to the Declaration on the Right to Development, to an understanding of the RTD that is not shared by many developed countries. Due to the absence of a functional approach to the definition of the RTD, the AU and Non-Aligned Movement (NAM) see a discrepancy between official commitments to the RTD and its absence in cooperation policies. This challenge has further led to the absence of a clear RTD based approach especially in terms of the international cooperation between developed and developing countries and thus hindering the realization and implementation of this right in developing countries.

Sixth, contrary to the general perception, it is not obvious that the main challenge to the realization of the RTD is predominantly political one (Salama, 2008). The principle problem is also related to the lack of conceptual clarity. The two major obstacles in this respect are the weaknesses of innovative conceptual thinking on the right to development within both developmental literature and human rights literature (Salama, 2008). The second major deficiency is almost the total lack of empirical knowledge on the matter. These two points explain that despite their rhetoric of human rights, partnership agreements, including those concluded among developing countries, such as New Partnership for the Africa's Development (NEPAD), do not invoke the RTD. The same applies to the United Nations Development Assistance Framework (UNDAFs), Common Country Assessments (CCAs) and Poverty Reduction Strategy Papers (PRSPs). 
Furthermore, it is also striking to note the growing convergences between the RTD and the outcome of numerous UN conferences such as Beijing +5 , Copenhagen +5 and the Monterrey Consensus on Financing Development (Salama, 2008). The fact that explicit reference to the RTD was avoided in all these related areas of international cooperation is indeed quite significant and it is far from being an accidental omission. It rather indicates that the RTD framework is not yet an understandable convincing operational tool for development. Hence, the lack of reference to the RTD in relevant UN forums and beyond indicates that the human rights community, including at the individual states level, has not yet been sufficiently associated, if at all associated, with the preparatory stages of policymaking and standard-setting exercises in the areas related to the RTD.

Eighth, there are two problems with the RTD in theory and practice. The first problem has to do with the separation between RTD and the concept of sustainable development (Wang, 2008). Sustainable development is not mentioned in the Declaration on the Right to Development, adopted by the UN General Assembly in 1986, although as a concept it has been accepted since the 1980's and the relationship between the RTD and sustainable development has even been discussed in the literature (Ginther, Denters, \& Waatt, 1995). The second problem is that sustainable development is expressed in terms of obligations and duties of human rights towards nature rather than as a human right (Wang, 2008). Both of these problems severely limit the potential for the protection and implementation of the RTD and sustainable development.

In summary, the issues raised above are only some of the challenges faced by developing countries in the realization and implementation of the RTD. Thus, in order to deliver results in an international context, it is necessary to work from a common starting point towards common goals with a common understanding of the key concepts to the RTD. In the case of the RTD, it is paramount to pursue the politically difficult process of finding consensus around the legal form and standing of the right. Otherwise, isolated efforts to realize and implement it without a solid legal foundation will remain unsustainable.

\section{Conclusion}

The RTD has been part of the international debate on human rights for over thirty years (Alston, 1988) but has not yet entered the practical realm of development planning and implementation. States tend to express rhetorical support for this right but neglect its basic precepts in development practice (Marks, 2004). After the Vienna Conference on Human Rights of 1993 and several other international conferences and summits, the right to development is now recognized as a 'human right' like other internationally accepted human rights. It clarifies norms and standards of behaviour in different societies, providing grounds for individuals to claim their rights, which the authorities at the national and international level are obliged to fulfill. Today, the discourse has now shifted towards implementation of the RTD and mechanisms and policies to be adopted by the authorities to enable the realization of this right in a progressive manner. With all the above challenges in mind, 
there is no doubt that developing countries have a long way to go in the realization of the RTD. What is urgently needed is a conducive environment to enable developing countries to deliver this right to their respective citizens. For the RTD to be realized, this would require formulating a development programme, consisting of coordinated policies involving both developed and developing countries. Furthermore, in order to formulate the RTD in terms of binding obligations there is also a need to persuade the society to accept them as binding obligations. Once the obligations are deemed binding, it would be necessary to work out a mechanism of enforcement, whether in the domestic legal system or under international law or through a process of peer pressure and moral suasion. But, these issues have to be examined in terms of accepted legal principles and procedures- a process that may take some time and persistence in consensus building.In other words, there should be no ambiguity regarding the current status of the idea of a legally-binding instrument on the RTD.

Looking at the challenges addressed above, it is inevitable to point out that developing countries are indeed at a cross-road in their quest for the realization of the RTD to their citizens. For developing countries to fulfill their corresponding obligations of delivering the enjoyment of this right to their citizens, what we need is a new approach, a combination of a political will, sustained commitment, conceptual clarity, creative thinking, a collaborative action through partnerships involving all relevant stakeholders, and, finally, sound joint expertise informing the political decision. Perhaps it is important to make reference to the past four sessions of the Working Group on the RTD held in Geneva, from 2004-2007 as well as the Millennium Development Goals (MDGs) especially Goal 8, which aims at developing a "global partnership for development," the RTD has come into the focus of renewed interest. The MDGs are those goals for development that were named in the Millennium Declaration (A/RES/55/2). The past four sessions of the Working Group on the RTD have adopted a new, innovative and dynamic approach to the RTD. This approach has made the RTD more technically challenging and politically less divisive (Malhotra, 2010). However, as a matter of caution, the author would like to point out that this positive development is fragile. Its sustainability depends on the behaviour of all relevant actors. It requires hard work, creative thinking, good faith and political commitment. It requires in particular a more active role by academic and non-governmental circles to shape a viable and constructive road-map for the RTD.

All in all, as far as the RTD and its advancement is concerned, it is now important that all sides recognize the importance of both national and international level of its scope and embrace both as complementary, not contradictory. The human person is definitely still at the centre of the RTD, and only the obligations involved transcend national borders (Marks, 2010). Only when a State is not in the position to fulfill this right for its citizens, or when the international environment is hostile to this fulfillment, can the international community be called upon to act. Hence, developing countries have a role to play and this role comes in the form of a duty by virtue of Art 3 of the Declaration on the Right to Development. It is the responsibility of developing countries to be strongly committed to good governance i.e. rooting out corruption, upholding human rights, and adherence to the rule of law since all these are essential conditions for successful development. Developing countries also need to 
have sound economic policies that foster enterprise and entrepreneurship such as more open markets, sustainable budget policies, and strong support for individual entrepreneurship that would act as a catalyst for lasting growth and prosperity.

\section{References}

Abi-Saab, G. (1980). The legal formulation of a right to development. In Dupuy, R. J. (Eds.), The right to development at the international level (pp. 159-175). The Hague: Sijthoff \& Noorddhoff.

Alston, P. (1988). Making space for new human rights: The case of the right to development. Harvard Human Rights Y.B, 3, 20.

Bedjaoui, M. (1991).The right to development. In M. Bedjaoui, (Eds.), International law: Achievements and prospects (pp. 1177-1182). Paris: UNESCO Publishing.

Beetham, D. (2010). The right to development and its corresponding obligations. In B. A. Andreassen, \& S. P. Marks (Eds.), Development as a human right-Legal, political and economic dimensions (pp.101-120). Belgium: Intersentia.

Development is Human Rights for all. (1996-2013). Retrieved from http://www.ohchr.org/ en/Issues/Developments/Pages/InformationMaterials.aspx

Donnelly, J. (1985). In search of the unicorn: The jurisprudence and politics of the right to development. California Western International Law Journal, 15, 473-482.

Ginther, K., Denters, E., \& Waatt, P. J. (1995). Sustainable development and good governance. London: Maritinus Nijhoff Publishers.

Iqbal, K. (2007). The declaration on the right to development and implementation. Political Perspectives Graduate Journal, 1(1), 1-39. Retrieved from http://www. politicalperspectives.org.uk/

Kenig-Witkowska, M. (1988).The UN declaration on the right to development in the light of its travaux preparatoires. In S. R. et al., Chowdhury (Eds.), International law and development (pp. 381-387). Netherlands: Martinus Nijhoff Publishers.

Kirchmeier, F. (2006). The right to development- where do we stand? Geneva: Friedrich Ebert Stiftung.

Lindroos, A. (1999). The right to development (Research Report Number 2/1999). Helsinki: The Erik Castren Institute of International Law. Retrieved from http://www.helsinki. 
Malhotra, R. (2010). Towards implementing the right to development. In B. A. Andreassen, \& S. P. Marks (Eds.), Development as a human right-Legal, political and economic dimensions (pp. 245-272). Belgium: Intersentia.

Marks, S. (2004). The human rights to development: Between rhetoric and reality. Harvard Human Rights Journal, 17, 139-168.

Marks, S. P. (2010). Obligations to implement the right to development: Philosophical, political and legal rationales. In B. A. Andreassen, \& S. P. Marks (Eds.), Development as a human right-Legal, political and economic dimensions (pp. 73-100). Belgium: Intersentia.

Salama, I. (2008). The right to development: Renewal and potential. In S. P. Marks (Eds.), Implementing the right to development- The role of international law (pp.117-126). Geneva: Friedrich Elbert Stiftung.

Sen, A. (2010). Human rights and development. In B. A. Andreassen, \& S. P. Marks (Eds.), Development as a human right-Legal, political and economic dimensions (pp. 3-12). Belgium: Intersentia.

. (1999). Development as freedom. Oxford: Oxford University Press.

Sengupta, A. (2010). The human right to development. In B. A. Andreassen, \& S. P. Marks (Eds.), Development as a human right-Legal, political and economic dimensions (pp. 13-44). Belgium: Intersentia.

. (2002). On the theory and practice of the right to development. Human Rights Quarterly, 24(4), 837-889.

Steiner, H. J., Alston, P., \& Goodman, R. (2008). International human rights in contextLaw politics morals. Oxford: Oxford University Press.

Symonides, J. (Ed.). (1998). Human rights: New dimension and challenges. Aldershot, England: Ashgate Publishing.

Turk, D. (1988). Participation of developing countries in decision-making process. In S. R. et al., Chowdhury (Eds.), International law and development (pp. 341-357). Netherlands: Martinus Nijhoff Publishers.

Wang, X. (2008). On the right to sustainable development: Foundation in legal philosophy and legislative proposals. In S. P. Marks (Eds.), Implementing the right to developmentThe role of international law (pp. 39-46). Geneva: Friedrich Elbert Stiftung. 
